\title{
Soft Tissue Sarcoma
}

National Cancer Institute

\section{Source}

National Cancer Institute. Soft Tissue Sarcoma. NCI Thesaurus. Code C9306.

A malignant neoplasm arising from muscle tissue, adipose tissue, blood vessels, fibrous tissue, or other supportive tissues excluding the bones. 